\title{
Efektivitas Sistem Informasi Akuntansi dan Kemampuan Teknis Pengguna pada Kinerja Individual Lembaga Perkreditan Desa
}

\author{
Ni Putu Meydiani Chintia Dewi1 \\ Fakultas Ekonomi dan Bisnis \\ Universitas Udayana, Indonesia \\ Email: meydiyepo@yahoo.com
}

\author{
A.A.N.A. Kresnandra ${ }^{3}$ \\ Fakultas Ekonomi dan Bisnis \\ Universitas Udayana, Indonesia
}

\author{
Ayu Aryista Dewi2 \\ Fakultas Ekonomi dan Bisnis \\ Universitas Udayana, Indonesia
}

\begin{abstract}
ABSTRAK
Kinerja individu sangat mempengaruhi keberhasilansuatuorganisasi. Setiap individu diharapkan dapat bekerja secara optimal agartujuan perusahaan dapat tercapai dengan maksimal. Terdapat beberapa faktor yang dapat mempengaruhi kinerja individual, diantaranya adalah efektivitas sistem informasi akuntansi dan kemampuanteknis pengguna. Penelitian ini dilakukan untuk memperoleh bukti empiris mengenai pengaruh efektivitas sistem informasi akuntansi dan kemampuan teknis pengguna pada kinerja individual. Penelitianini dilakukan di 35 LPD Kota Denpasar. Sampel penelitian ini sebanyak 105 responden dengan metode penentuan sampel purposive sampling. Pengumpulan data dilakukan dengan cara penyebaran kuesioner. Teknik analisis yang digunakan adalah regresi linier berganda. Berdasarkan hasil penelitian ini menunjukkan bahwa efektivitas sistem informasi akuntansi dan kemampuan teknis pengguna berpengaruh positif pada kinerja individual.

Kata Kunci: Efektivitas Sistem Informasi Akuntansi; Kemampuan Teknis Pengguna; Kinerja Individual.

The Effectiveness of Accounting Information Systems and the Technical Capabilities of Users of the Individual Performance of Village Credit Institutions
\end{abstract}

\begin{abstract}
Individual performance greatly influences the success of an organization. Each individual is expected to work optimally so that the company's soalscan be achieved to the maximum. There are several factors that can affect individual performance, among which are the effectiveness of accounting information sustems and the user's technical abilitu. This research was conducted to obtain empirical evidence regarding the effect of the effectiveness of accounting information sustems and the user's technical abilitu on individual performance. This research was conducted in 35 LPD inDenpasar City. The sample of this research was 105 respondents with a purposive sampling method. Data collection is done bu distributing questionnaires. The analysis technique used is multiple linear regression. Based on the results of this study indicate that the effectiveness of accounting information sustems and the user's technical ability has a positive effect on individualperformance.

Keywords: Accounting Information System Effectiveness; User Technical Capabilities; Individual Performance.
\end{abstract}

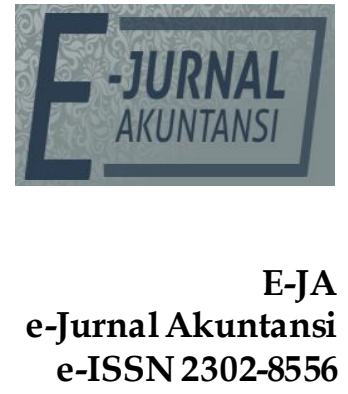

Vol. 30 No.7

Denpasar, Juli 2020 Hal.1633-1644

Artikel Masuk: 25 Februari 2020

Tanggal Diterima: 3 Maret 2020

This Article is Avalilable in: https://ojs.unud.ac.id/index.php/Akuntansi/index 


\section{PENDAHULUAN}

Tidak dapat dipungkiri bahwa kemajuan teknologi informasi telahmengubahcara hidup masyarakat di dunia dalam menjalankan aktivitas sehari-hari. Perkembangan teknologi yang terus mengalami kemajuan, memungkinkan berbagai kegiatan dilakukan dengan lebih cepat, tepat dan akurat sehingga dapat meningkatkan produktivitas seorang individu atau bahkan suatu organisasi (DeLone \& McLean, 1992). Jayantara \& Dharmadiaksa (2016) menyatakanbahwa perkembangan teknologi informasi berdampak signifikan terhadap sistem informasi akuntansi (SIA). Sistem informasi akuntansi menjadi sarana penting untuk mendukung tersedianya informasi keuangan yang berkualitas karena digitalisasi informasi (Yuhelson et al., 2020) serta kinerja organisasi yang lebih baik yang tercermin dari adanya peningkatan kinerja individual.

Optimalisasi dari kinerja individual (DeLone \& McLean, 1992) tidakhanya diperlukan oleh perusahaan- perusahaan besar, namun juga oleh lembaga keuangan dengan skala lebih kecil seperti Lembaga Perkreditan Desa. LPD dibandingkan dengan lembaga keuangan lainnya memiliki sifat yangkhas, karena dilihat dari dasar konstitusional, dasar hukum, asal-usul, tujuan, serta pola kerja yang sangat berbeda dengan lembaga keuangan lainnya (Jayantara \& Dharmadiaksa, 2016). Perbedaan lainnya dapat dilihat dalam cara pemilihan anggota. LPD dalam memilih anggota kepengurusan lebih mengutamakan musyawarah dan mufakat dalam sebuah paruman.

Dalam cara pemilihan kepengurusan seperti ini, muncul keraguan kinerja LPD akan dapat ditingkatkan. Hal tersebut dikarenakan anggota pengurus yang dipilih dengan cara paruman bisa saja memiliki kemampuan yang kurang sesuai. Hal berpengaruh ke kinerja individual cenderung kurang optimal dan akan berpengaruh terhadap kinerja organisasi. Tetapi kenyataanya total aset LPD di Provinsi Bali mengalami peningkatan, salah satunya adalah LPD Kota Denpasar.

Kenaikan total aset tersebut dapat dicapai karena adanya program pembinaan LPD dengan sistem pengelolaan secara komputerisasi guna meningkatkan kinerja karyawan LPD (Tribun Bali.com, 2018). Berdasarkandata Lembaga Pemberdayaan Lembaga Perkreditan Desa (LP LPD) tahun 2018, total aset LPD Kota Denpasar selama tahun 2016 - 2018 dapat dilihat pada Tabel 1, sebagai berikut:

Tabel 1. Perkembangan Total Aset LPD Kota Denpasar Tahun 2016-2018

\begin{tabular}{cc}
\hline Tahun & Total Aset LPD Kota Denpasar \\
\hline 2016 & 1,6 Triliun \\
2017 & 1,9 Triliun \\
2018 & 2,2 Triliun \\
\hline
\end{tabular}

Sumber: LP LPD Kota Denpasar 2018

Berdasarkan data pada Tabel 1, dapat dilihat bahwa total aset LPDdiKota Denpasar mengalami peningkatan setiap tahunnya selama tiga tahun terakhir yaitu sejak tahun 2016-2018. Hal tersebut menandakan bahwa partisipasi masyarakat dengan adanya LPD di Kota Denpasar semakin besar. Kepemilikan aset yang semakin besar, diiringi dengan volume transaksi yang semakin kompleks, sehingga pengolahan data dengan SIA berbasis komputer sangat diperlukan untuk mendukung optimalisasi kinerja karyawan LPD (Alannita \& Suaryana, 2014). Selain efektivitas sistem informasi akuntansi, beberapa peneliti 
menyatakan bahwa kinerja individual juga dipengaruhi oleh kemampuan teknis pengguna sistem informasi akuntansi tersebut. Widyasari \& Suardikha (2015) menyatakan, pengguna sistem memiliki peranan yang penting dalam kemajuan suatu perusahaan karena pengguna sistem informasi dapat mendorong kinerja sistem informasi menjadi baik sehingga dapat meningkatkan kinerja individual. Begitu juga Garrison et al., (2015), berpendapat bahwa kemampuan teknis dari pengguna suatu sistem adalah kunci untuk mewujudkan kesuksesan dari sebuah organisasi.

Penelitian ini mengacu pada penelitian terdahulu yang telah dilakukan oleh (DeLone \& McLean, 1992) dan Trabulsi (2018) yang meneliti tentang dampak sistem informasi akuntansi pada kinerja organisasi UKM yang ada di Arab Saudi dan memperoleh hasil bahwa penggunaan sistem informasi akuntansi berpengaruh secara signifikan pada kinerja organisasi UKM yang ada di Arab Saudi. Peningkatan kinerja meliputi adanya peningkatan kualitas, pengurangan biaya serta peningkatan efektivitas dalam pengambilan keputusan.

Perbedaan dari penelitian ini dengan penelitian terdahulu, yaitu penelitianini mengukur variabel kinerja individual dan kemampuan teknis pengguna sistem informasi akuntansi. Perbedaan lainnya adalah dalam penelitian memilih untuk menggunakan LPD di Kota Denpasar sebagai objek penelitian. LPDkotaDenpasar dipilih sebagai objek penelitian karena terdapat fenomena kenaikan total aset selama tiga tahun terakhir yaitu sejak tahun 2016-2018 yang terjadi di LPD Kota Denpasar yang disebabkan oleh adanya penerapan sistem informasi akuntansi berbasis komputer.

Berdasarkan latar belakang yang telah dikembangkan maka dapat ditarik rumusan masalah yaitu: 1)Apakah efektivitas sistem informasi akuntansi berpengaruh terhadap kinerja individual LPD Kota Denpasar? 2)Apakah kemampuan teknis pengguna sistem informasi akuntansi berpengaruh terhadap kinerja individual LPD Kota Denpasar? Tujuan dari penelitian ini adalah:1) Untuk memperoleh bukti empiris mengenai pengaruh efektivitas sistem informasi akuntansi pada kinerja individual LPD Kota Denpasar, 2) Untuk memperoleh bukti empiris mengenai pengaruh kem.mpuan teknis pengguna terhadap kinerja individual LPD Kota Denpasar. Penelitian ini dapat memberikan manfaat teoretis berupa sumbangan pengetahuan mengenai teori Technology Acceptance Model dan teori Technology-to-Performance Chain, sehingga kedepannya dapat dijadikan refrensi bagi peneliti selanjutnya. Hasil dari penelitian ini juga dapat memberi masukan bagi pihak terkait di LPD Kota Denpasar agar dapat mencapai tujuan organisasi yang lebih maksimal.

Model TAM menjelaskan bahwa persepsi pengguna akan menentukan sikapnya dalam penggunaan teknologi informasi dan menggambarkan tentang penggunaan teknologi informasi yang dipengaruhi oleh persepsi kemanfaatan dan persepsi kemudahan. Davis (1986), menyatakan bahwa persepsi kemanfaatan merupakan suatu ukuran dimana penggunaan suatu teknologi dipercaya dapat mendatangkan manfaat bagi orang yang menggunakannya. TAM bertujuanuntuk menyediakan gambaran yang mendasari pengaruh faktor-faktor eksternal terhadap kepercayaan internal, sikap dan tujuan (Gunawan \& Tenaya, 2017). Suatu sistem informasi dikatakan efektif apabila telah digunakan secara maksimal dan memberi manfaat yang maksimal kepada pengguna sistem informasi 
tersebut. Untuk memaksimalkan penggunaan suatu sistem, selain persepsi mengenai sistem tersebut, juga diperlukan kemampuan teknis yang memadai yang dimiliki oleh pemakai sistem. Semakin mudah dan semakin banyak manfaat yang diberikan suatu sistem dalam penin.gkatan kinerja, maka individu akan menggunakan teknologi tersebut dengan baik.

Technology-to-Performance Chain (TPC) adalah suatu model yang digunakan dalam memahami sikap pemakai sebagai predictor dari pemakai dan kesesuaian tugas dengan teknologi sebagai predictor kinerja individu (Sridarmaningrum \& Widhiyani, 2018). Dalam konsep TPC, timbal balik dari dampak kinerja yang baik merupakan cerminan dari keberhasilan penerapan sistem informasi yang dijalankanModel ini mengindikasikan bahwa kinerja akan meningkat apabila sebuah teknologi menyajikan fitur dan dukungan yang tepat dikaitkan dengan teknologi . Dalam teori ini secara tidak langsung menggambarkan bahwa kinerja karyawan dapat ditingkatkan apabila suatu teknologi sistem informasi telah beroperasi secara efektif dan dipergunakan dengan teknis serta kemampuanyang memadai.

Kinerja individual dapat diartikan sebagai tingkat keberhasilan seseorang secara keseluruhan selama periode tertentu dalam melaksanakan tugas yang telah ditargetkan. Kinerja individual merupakan kemampuan individu untuk melakukan sesuatu dengan berhasil dan efesien pada suatu perusahaan (Jayantara \& Dharmadiaksa, 2016).

Bodnar (2006: 3), menyatakan sistem informasi akuntansi merupakan kumpulan dari peralatan dan manusia (sumber daya) yang dibuat untuk mengubah data-data keuangan ke dalam bentuk yang bermanfaat bagi pengguna dan berguna bagi pemakainya. Sugiantara (2017), menyatakan sistem informasi akuntansi sebagai komponen dan elemen dari suatu organisasi yang menyediakan informasi bagi pengguna dengan pengolahan peristiwa keuangan. Sistem yang efektif didefinisikan sebagai sistem yang dapat memberikan pengaruh positif kepada pemakainya (Trabulsi, 2018). Efektivitas suatu sistem informasiakuntansi yaitu ukuran yang memberikan kontribusi dalam pembuatan keputusan melalui suatu kumpulan sumber daya yang dikumpulkan, diproses dan disimpan dalam data elektronik, yang kemudian diubah menjadi suatu informasi yang dapat berguna. Kemampuan teknis pengguna merupakan rata-rata pendidikan atau tingkat pengalaman dari seseorang. (Widyasari \& Suardikha, 2015). Garrisonetal., (2015) berpendapat bahwa kemampuan teknis dari pengguna suatu sistemadalah kunci untuk mewujudkan kesuksesan dari sebuah organisasi. Oleh karena itu, perusahaan akan sangat selektif ketika melakukan perekrutan karyawan, untuk memperoleh karyawan dengan kemampuan teknik personal yang baik.

Dalam Technology Acceptance Model Theory (TAM), menerangkan jika setiap individu pengguna SIA (karyawan) merasakan kemudahan dan mampu menerima manfaat dari suatu sistem informasi akuntansi, maka pekerjaan karyawan tentu akan dipermudah dengan adanya sistem tersebut. Teori Technology-to-Performance Chain (TPC) juga menyatakan bahwa timbal balik dari dampak kinerja yang baik merupakan cerminan dari keberhasilan penerapan sistem informasi yang dijalan.kan. Ha.l tersebut menunjukkan semakin efektif suatu sistem maka kinerja akan semakin meningkat. Hasil penelitian terdahulu yang telah dilakukan oleh Trabulsi (2018), Dewi \& Dharmadiaksa (2017), Dewi\& 
Dharmadiaksa (2019), bahwa efektivitas sistem informasi akuntansi berpengaruh positif terhadap kinerja individual. Berdasarkan pemaparan tersebut, makadapat dirumuskan hipotesis penelitian yaitu:

$\mathrm{H}_{1}$ : Semakin efektif penerapan suatu sistem informasi akuntansi, maka kinerja individual akan semakin meningkat.

Pengguna sistem informasi akuntansi dalam suatu perusahaan sebaiknya didukung oleh kemampuan personal pemakai sistem informasi tersebut, sehingga penggunaan suatu sistem informasi akuntansi akan mampu meningkatkan kinerja perusahaan dan individu itu sendiri. Technology Acceptance Model Theory (TAM) menyatakan bahwa prilaku pengguna suatu sistem informasi bergantung pada persepsinya mengenai kebermanfaatandan kemudahan penggunaan sistem tersebut. Semakin baik kemampuan teknis yang dimiliki oleh pengguna suatu sistem, maka akan semakin efektif sistem tersebut dioperasionalkan sehingga akan memberi manfaat yang maksimal. Hasil penelitian terhadulu yang telah dilakukan oleh Garrison et al., (2015), Alannita \& Suaryana (2014), Widyasari \& Suardikha (2015), Dewi \& Suardikha (2015), Dewi \& Dharmadiaksa (2017), memperoleh hasil bahwa kemampuan teknis pengguna SIA berpengaruh positif terhadap kinerja individual. Berdasarkan pemaparan tersebut, maka dapat ditarik hipotesis yaitu:

$\mathrm{H}_{2}$ : Semakin baik kemampuan teknis pengguna SIA, maka kinerja individual akan semakin meningkat.

\section{METODE PENELITIAN}

Penelitian ini menggunakan pendekatan kuantitatif yang berbentuk asosiatif. Penelitian ini dilakukan di 35 LPD di Ko.ta Denpasar. Objek penelitian ini adalah kinerja individual yang diduga dipengaruhi oleh efektivitas SIA dan kemampuan teknis pengguna SIA. Variabel bebas dalam penelitian ini adalah efektivitas sistem informasi akuntansi (X1) dan kemampuan teknis pengguna (X2). Variabel terikat dalam penelitian ini adalah kinerja individual $(Y)$. Indikator pengukuran variabel efektivitas sistem informasi akuntansi (X1) terdiri dari tiga indik.ator yaitu, 1) Fleksibelitas, 2) Kemudahan dalam menggunakan, 3) Sistem realibilitas (DeLone \& McLean, 2003) dalam Gita Sari, (2018). Variabel kemampuan teknis pengguna $\left(\mathrm{X}_{2}\right)$ menurut Robbins (2008 : 45) menyatakan ada tiga indikator untuk mengukur kemampuan teknik pemakai sistem informasi akuntansi, yaitu 1) pengetahuan,2) kemampuan, 3) keahlian. Terdapat tiga indikator yang dapat digunakan untuk mengukur kinerja individual (Y) yaitu, 1) kuantitas kerja (quantity), 2) kualitas kerja (quality), 3) ketepatan waktu (timeliness) (Sridarmaningrum \& Widhiyani, 2018).

Jenis adata dalam penelitian ini berupa data kuantitatif dan kualitatif. Data kuantitatif dalam penelitian ini berupa hasil jawaban kuesioner yang disajikan dalam bentuk Skala Likert. Sedangkan untuk data kualitatif dalam penelitian ini adalah penjelasan mengenai teori-teori yang berkaitan dengan variabelyang akan diteliti. Sumber data dalam penelitian ini berupa data primer yaitu hasil jawaban responden dan data sekunder berupa data lokasi LPD Kota Denpasar. Dalam pen.elitian ini menggunakan kuesioner sebagai instrumen penelitian. Kuesioner diukur. Menggunakan skala likert 4 poin. Uji validditas dan reliabilitas dilakukan sebagai prasyarat uji instrumen. 
Populasi dalam penelitian ini adalah 480 orang karyawan yang bekerja di 35 LPD yang ada di Kota Denpasar. Sampel dalam penelitian adalah 105 orang responden. Metode penentuan sampel yang digunakan adalah purposive sampling. Teknik analisis dalam penelitian ini melip.uti uji stati.stik desk.riptif, uji asumsi klasik yang terdiri dari uji normalitas, multikolinieritas dan heteroskedastisitas, uji regresi linier berganda, uji koefisien determinasi, uji F dan uji hipotesis (uji t) dengan tingkat signifikan 5\%. Adapun rumus regresi liner berganda adalah:

$\mathrm{Y}=\mathrm{a}+\mathrm{b}_{1} \mathrm{X}_{1}+\mathrm{b}_{2} \mathrm{X}_{2}+\varepsilon$

\section{HASIL DAN PEMBAHASAN}

Pengujian instrumen pen elitian dilakukan den gan uji vali ditas dan reliabilitas. Berdasarkan uji val iditas diperoleh hasil bahwa setiap item pertanyaan dari masing- masing variabel kinerja individual $(Y)$, efektivitas sist em info rmasi aku ntansi $\left(X_{1}\right)$ da $n$ kema mpuan tek nis penggu na SIA $\left(X_{2}\right)$ pada kuesioner memiliki nilai koefisien kolerasi lebih besar da ri 0,3, sehingga pertanyaandalam kuisioner yan g digun akan dinyatakan valid. Hasil uji reliabilitas menunjukkan bahwa nilai Cronbach's Alpha masing-masing variabel pada kuesioner meliputi variabel kinerja individual $(\mathrm{Y})$, efektivitas sistem informasi akuntansi $\left(\mathrm{X}_{1}\right)$ dan kemampuan teknis pengguna SIA $\left(\mathrm{X}_{2}\right)$ lebih besar dari 0,7 maka dapat disimpulkan bahwa kuesioner yag digunakan sudah reliabel.

Tabel 2. Hasil Analisis Statistik Deskriptif

\begin{tabular}{lccccc}
\hline \multicolumn{1}{c}{ Variabel } & $\mathrm{N}$ & Minimum & Maksimum & Mean & Standar Deviasi \\
\hline Efektivitas SIA $\left(\mathrm{X}_{1}\right)$ & 105 & 2,8 & 4 & 3,186 & 0,293 \\
Kemampuan Teknis & & 2,4 & 3.4 & 2,790 & 0,235 \\
Pengguna SIA $\left(\mathrm{X}_{2}\right)$ & 105 & & 4 & 3,308 & 0,365 \\
Kinerja Individual $(\mathrm{Y})$ & 105 & 3 & 4 &
\end{tabular}

Sumber: Data Penelitian, 2019

Berdasarkan Tabel 2, diperoleh nilai minimum dari jumlah skor jawaban responden untuk variabel efektivitas sis tem inf ormasi akunt ansi $\left(X_{1}\right)$ adalah 2,8 dan nilai maksimumnya adalah 4 . Nilai rata-rata sebesar 3,1867 menunjukkan bahwa responden cenderung merasa setuju pada masing-masing item pernyataan dalam kuesioner, artinya efektivitas sistem informasi akuntansiyang diiterapkan di LPD Kota Denpasar sudah mampu memberikan keamanan bagi data yang disimpan, membuat waktu pelayanan menjadi lebih singkat, membuat penyajian data menjadi lebih teliti dan mampu memberikan kemudahan dala $\mathrm{m}$ penyediaan laporan yang lebih variatif. Stand ar deviasi sebesar 0,29387, berarti perbedaan tingkat efektivitas sistem inf ormasi yang diteliti terhada p nilai rataratanya sebesar 0,29387 .

Berd asarkan Tabel 2. diperoleh nilai minimum dari jumlah skor jawaban responden untuk variabel kemampuan teknis pengguna SIA $\left(X_{2}\right)$ adalah 2,4 dan nilai maksimumnya adalah 3,4. Nilai rata-rata sebesar 2,7905 menunjukkan bahwa responden cenderung menjawab tidak setuju pada item pernyataandalam kuesioner. Responden cenderung menjawab setuju pada pernyataan satu sampai dengan tiga, sedangkan jawaban tidak setuju cenderung diberikan padaduaitem pernyataan yang menyatakan hambatan yang dialami oleh pengguna sistem. Hasil tersebut menunjukkan kemampuan teknis pengguna SIA cenderung tinggi, 
karena berdasarkan jawaban yang diberikan menandakan bahwa pengguna SIA di LPD Kota Denpasar merasa telah memiliki kemampuan yang cukup tentang SIA serta sebagian besar tidak merasa kesulitan dalam memahami dan mengoperasionalkan sistem informasi akuntansi saat bekerja. Standar deviasi sebesar 0,23956, berarti perbedaan tingkat efektivitas sistem inf ormasi yang diteliti terha dap nilai rata-ratanya sebesar 0,23956.

Berdasarkan Tabel 2. diperoleh nilai minimum dari jumlah skor jawaban responden untuk variabel kinerja individual $(\mathrm{Y})$ adalah 3 dan nilai maksimumnya adalah 4. Nilai rata-rata sebesar 3,3086 menunjukkan bahwa responden cenderung merasa setuju pada masing-masing item pernyataan dalam kuesioner. Hasil tersebut menunjukkan kinerja individual cenderung tinggi karena responden memberikan jawaban yang menandakan bahwa produktifitas pekerjaan meningkat, tanggung jawab dapat terlaksana lebih baik dan pemberian pelayanan menjadi lebih baik. Standar deviasi sebesar 0,36588 , berarti perbedaan tingkat efektivitas sistem informasi yang diteliti terhadap nilai rata-rata nya sebesar 0,36588 .

Uji normalitas bertujuan untuk mengetahui apakah data yang digunakan dalam penelitian ini berdistribusi nor mal atau tidak. Jika Asymp.Sig. (2-tailed) $>a$ $=5 \%$ maka data residual tersebut berdistribusi secara normal, sedangkan jika Asymp.Sig. (2-tailed) $<a=5 \%$ maka data tidak berdistribusi secara normal (Ghozali, 2016:160). Hasil uji normalitas dapat dilihat pada Tabel 3 sebagai berikut:

\section{Tabel 3. Hasil Uji Normalitas}

\begin{tabular}{lc}
\hline Kolmgorov-Smirnov Z & Unstandarized Residual \\
\hline $\mathrm{N}$ & 105 \\
Asymp.Sig. (2-tailed) & 0,149 \\
\hline
\end{tabular}

Sumber: Data Penelitian, 2019

Berdasarkan data pada Tabel 3. tersebut, hasil uji normalitas menunjukkan bahwa nilai Asymp. Sig. (2-tailed) yang dihasilkan adalah sebesar 0,149. Nilaiyang dihasilkan ini lebih besar dari signifikan 0,05 sehingga dapat disimpulkan bahwa data telah terdistribusi normal.

Uji Multikolinearitas bertujuan untuk menguji apakah dalam regresi ditemukan adanya korelasi antar variabel bebas (Ghozali, 2016:105). Deteksi adanya gejala multikolinearitas dapat dilakukan dengan melihat nilai tolenancedan VIF (Varian Inflation Factor) dengan kriteria yaitu, jika nilai tolerance $>0,1$ dannilai VIF < 10, maka dikatakan bahwa tidak ditemukan adanya gejala multikolinearitas pada model regresi, sebaliknya jika nilai tolerance $<0,1$ dan nilai VIF >10, maka dikatakan bahwa ditemukan adanya gejala multikolinearitas pada model regresi. Hasil uji multikolinearitas dapat dilihat pada Tabel 4, sebagai berikut:

Tabe 14 . Has il Uji Multik olinearitas

\begin{tabular}{lcc}
\hline \multicolumn{1}{c}{ Variabel } & Tolerance & VIF \\
\hline Efektivitas Sistem Informasi Akuntansi & & \\
$\left(\mathrm{X}_{1}\right)$ & 0,358 & 2,792 \\
Kemampuan Teknis PenggunaSIA $\left(\mathrm{X}_{2}\right)$ & 0,358 & 2,792 \\
\hline
\end{tabular}


Berdasarkan hasil olah data pada Tabel 4. menunjukkan bahwa untuksemua variabel independen yang diguna kan memiliki nilai tolerance lebih be sar dari0,1 dan nilai VIF yang dihasilkan kurang dari 10, sehingga dapat disimpulkan bahwa tid ak terjadi kor elasi ganda (multikolinieritas) antar variabel bebas.

Uji heteroskedasitas digunakan untuk meng ukur sama atau tidaknya variance dari residual observasi satu dengan observasi lainnya. Penelitian ini menggunakan uji Glejser dimana dilakukan dengan meregresikan nilai absolute resid ual terhadap variabel bebas. Apa bila nilai signifikansi variabel bebasnya terhadap nilai absolute residual $>\mathrm{a}=0,05$, maka dapat dikatakan bahwa model regresi tidak mengandung heterokedastisitas. Hasil uji heteroskedastisitas dapat dilihat pada Tabel 5, sebagai berikut:

Tabel 5. Hasil Uji Heteroskedastisitas

\begin{tabular}{lcc}
\hline Variabel & Signifikansi & Keterangan \\
\hline $\begin{array}{l}\text { Efektivitas Sistem Informasi } \\
\text { Akuntansi }\left(\mathrm{X}_{1}\right)\end{array}$ & 0,841 & Bebas \\
$\begin{array}{l}\text { Kemampuan Teknis PenggunaSIA } \\
\left(\mathrm{X}_{2}\right)\end{array}$ & 0,423 & $\begin{array}{c}\text { Heteroskedastisitas } \\
\text { Bebas }\end{array}$ \\
\hline
\end{tabular}

Sumber: Data Penelitian, 2019

Berdasarkan data pada Tabel 5, dapat diketahui bahwa semua variabelbebas yang digunakan pada penelitian yaitu, efektivitas sistem informasi akuntansi $\left(\mathrm{X}_{1}\right)$ ) dan kemampuan teknis pengguna SIA $\left(X_{2}\right)$ memiliki nilai lebih besar dari 0,05 sehingga dapat disimpulkan bahwa tidak terjadi gejala heterokedasitas.

Tabel 6. Hasil Uji Regresi Lini er Berganda

\begin{tabular}{|c|c|c|c|c|c|}
\hline \multirow[t]{2}{*}{ Model } & \multicolumn{2}{|c|}{ Unstandardized Coefficients } & \multirow{2}{*}{$\begin{array}{c}\begin{array}{c}\text { Standardized } \\
\text { Coefficients }\end{array} \\
\text { Beta }\end{array}$} & \multirow[t]{2}{*}{$\mathrm{t}$} & \multirow[t]{2}{*}{ Sig. } \\
\hline & B & $\begin{array}{l}\text { Std. } \\
\text { Error }\end{array}$ & & & \\
\hline $\begin{array}{l}\text { (Constant) } \\
\text { Efektivitas }\end{array}$ & 0,725 & 0,171 & & 4,234 & 0,000 \\
\hline $\begin{array}{l}\text { Sistem Informasi } \\
\text { Akuntansi }\left(\mathrm{X}_{1}\right) \\
\text { Kemamnuan }\end{array}$ & 0,509 & 0,066 & 0,547 & 7,648 & 0,000 \\
\hline $\begin{array}{l}\text { Kemampuan } \\
\text { Teknis Pengguna } \\
\text { SIA }\left(X_{2}\right)\end{array}$ & 0,345 & 0,061 & 0,403 & 5,635 & 0,000 \\
\hline Adjusted R Square & 0,810 & & & & \\
\hline $\begin{array}{l}\text { F Hitung } \\
\text { SignifikansiF }\end{array}$ & $\begin{array}{r}222,348 \\
0,000\end{array}$ & & & & \\
\hline
\end{tabular}

Berdasarkan Tabel 6, maka dapat diketahui bahwa analisis linier berganda efektivitas sistem informasi akuntansi $\left(X_{1}\right)$ dan kemampuan teknis penggunaSIA $\left(X_{2}\right)$ pada kinerja individual $(Y)$, memperoleh hasil koefisien $\beta 0=0,725, \beta 1=0,509$ dan $\beta 2=0,345$. Berdasarkan hasil tersebut maka model regresi linier bergandanya adalah sebagai berikut:

$$
\mathrm{Y}=0.725+0.509 \mathrm{X}_{1}+0.345 \mathrm{X}_{2}
$$

Nilai konstanta benilai positif sebesar 0,725 maka dapat diartikan apabila tidak terdapat pengaruh dari variabel lain atau variable bebas, ma kanilaikonstan dari variabel kinerja individual $(Y)$ adalah sebe sar 0,725. Nilai koefisien variabel efektivitas sistem informasi akuntansi $\left(X_{1}\right)$ bernilai positif sebesar 0,509 maka 
artinya apabila nilai efektivitas sistem informasi akuntansi $\left(\mathrm{X}_{1}\right)$ naik satu sat uan dengan asumsi bahwa variabel lainnya konstan, maka kinerja individual (Y) akan naik sebesar 0,509. Nilai koefisien variabel kemampuan teknis pengguna SI A $\left(X_{2}\right)$ bernilai positif sebesar 0.345 maka artinya apabila nilai kemampuan teknis pengguna SIA $\left(X_{2}\right)$ naik satu satuan dengan asumsi bahwa variabel lainnya konstan,maka kinerja individual (Y) akan naik sebesar 0,345.

Analisis koefisien deter minasi merupakan besar nya kontr ibusi variabel bebas terhadap variabel terikat. Analisis koef isien deter minasi bertujuan untuk mengetahui seberapa be sar kemam puan variabel bebas menjelaskan variabel terikat. Koefisien determinasi yang digunakan adalah nilai dari Adjusted $R^{2}$. Berdasarkan Tabel 6, dapat dilihat bahwa nilai dari Adjusted $R^{2}$ adalah sebesar 0,810 atau 81 persen. Hal ini menandakan bahwa sebesar 81 persen variansi kinerja individual dapat dipengaruhi oleh variabel efektivitas sistem informasi akuntansi dan kema mpuan teknis pengguna SIA, sedangkan sis anya sebesar 19 persen dijelaskan oleh faktor-faktor lain yang tidak dijelaskan dalam model penelitian ini.

Uji statistik F dilakukan dengan tujuan untuk mengetahui apakah semua variabel be bas dalam model mempunyai pengaruh secara serempak terhadap variabel terikat. Hasil uji statistik $F$ dapat dilihat dengan memban dingkan ting kat signifikansi $F$ hitung dengan $\alpha=0,05$. Apabila tingkat signifikansi $F<a=$ 0,05 maka dapat dikatakan bahwa hubungan antar variabel bebas adalah signifikan dalam mempengaruhi kinerja individual sebagai variabel terik at. Berdasarkan data yang tercantum dalam Tabel 6, dapat diketahi bahwa signifikansi uji $\mathrm{F}$ adalah sebesar 0,000 yang lebih kecil dari 0,05. Hal tersebut menandakan bahwa variabel efektivitas sistem informasi akuntansi dan kemampuan teknis pengguna SIA tepat menjelaskan fenomena kinerja individual. Pernyataan tersebut memberikan makna bah wa model yang digunakan dalam penelitian ini adalah layak uji.

Uji t dilakukan untuk mengaruh secara parsial (per variabel bebas) dari masing-masing hipotesis terhadap variabel terikat. Hasil uji $t$ dapat dilihat dengan membandingkan tingkat signifikansi t hitung deng an $\alpha=0,005$. Apabila signif ikansi $t<0,05$ maka hipotesis yang diajukan dalam penelitian ini diter ima. Berdasarkan data dalam Tabel 6, dapat disimpulkan bahwa hasil dari ujihipotesis (uji t) adalah sebagai beri kut: Berdasarkan data dalam Tabel 6 dapat dilihat bahwa nilai tingkat signifikansi $t$ untuk variabel efektivitas sistem informasi akuntansi adalah sebesar 0,000 atau $t=0,000<0,05$. Hal ini mengindikasikan hipo tesis 1 yang menyatakan efek tivitas sistem informasi akunt ansiberpengaruh positif terhadap kinerja individual diterima ( $\mathrm{H}_{1}$ diterima). Berdasarkan data dalam Tabel 6 dapat dilihat bahwa nilai tingkat signifikansi t unt uk variabel kemampuan teknis pengguna SIA adalah sebesar 0,000 atau $t=0,000<0,05$. Ha 1 ini mengind ikasikan hipotesis 2 yang meny atakan kemampuan teknis pengguna SIA berpengaruh positif terhadap kinerja individual diterima $\left(\mathrm{H}_{2}\right.$ diterima).

Has il uji parsial pengaruh efektivitas sistem informasi akuntansi $\left(\mathrm{X}_{1}\right)$ terhadap kinerja individual (Y) pada Tabel 6, diperoleh nilai $p$-value 0,000 leb ih kecil dari 0,05. Hal ini menandakan bah wa efektivitas sist em informasiakuntansi berp engaruh signifikan terhadap kinerja indivual. Nilai koefisien regresi efektivitas sistem informasi akuntansi $\left(\mathrm{X}_{1}\right)$ dengan arah positif sebesar 0,509 
menunjukkan adanya pengaruh positif efektivitas informasi akuntansi pada kinerja indivual. Berdasarkan hasil tersebut maka hipotesis $1\left(\mathrm{H}_{1}\right)$ yang menyatakan bahwa semakin efektif penerapan suatu sistem informasi akuntansi, maka kinerja individual akan semakin meningkat dapat diterima.

Hasil penelitian ini sejalan dengan hasil penelitian terdahulu yang telah dilakukan oleh Trabulsi (2018), Dewi \& Dharmadiaksa (2017) serta Dewi \& Dharmadiaksa (2019) yang menyatakan bahwa efektivitas sistem informasi akuntansi berpengaruh positif terhadap kinerja individual. Hasil penelitian tersebut mendukung teo ri Technology Acceptance Model (T AM) yang menyatakan jika setiap individu pengg una SIA (karyawan) merasakan kemudahan dan kebermanfaatan dari suatu sistem informasi akuntansi, maka keinginan mereka untuk mengoperasionalkan sistem tersebut akan semakin tinggi. Semakinoptimal suatu sistem informasi akuntansi diimplementasikan, maka akan memberi dampak pada peningkatan kin erja indiv idual. Teori Technology-to-Performance Chain (TPC) juga menyatakan bahwa timbal balik dari dampak kinerja yang semakin meningkat merupakan cerminan dari keberhasilan penerapan sistem informasi yang dijalankan (Sridarmaningrum \& Widhiyani, 2018). Berdasarkan pernyataan tersebut, maka dapat disimpulkan bahwa semakin efektif implementasi sua tu sistem informasi akuntansi dalam perusahaan, maka kinerja individual juga semakinmenin gkat.

Hasil uji parsial pengaruh kema mpuan teknis pengguna SIA $\left(\mathrm{X}_{2}\right)$ terhadap kinerja individual (Y) pad a Tabel 6 diperoleh nilai $p$-value 0,000 lebih kecil dari 0,05 . Hal ini menandakan bah wa kemampuan teknis pengg una SIA berpengaruh signifikan terhadap kinerja indivual. Nilai koefisien regresi kemampuan teknis pengguna SIA $\left(X_{2}\right)$ memiliki arah positif sebesar 0,345 menunjukkan a\&ya pengaruh positif kemampuan teknis pengguna SIA terhadap kinerja indivual. Berdasarkan hasil tersebut maka hipotesis $2\left(\mathrm{H}_{2}\right)$ yang menya takansemakin baik kemampuan teknis pengguna SIA, maka kinerja individual akan semakin meningkat dapat diterima.

Hasil penelitian ini sejalan dengan hasil penelitian terhadulu yang telah dilakukan oleh Garrison et al., (2015), Alannita \& Suaryana (2014), Widyasari \& Suardikha (2015), Dewi \& Suardikha (2015) serta Dewi \& Dharmadiaksa (2017) yang menyatakan bahwa kema mpuan teknis pengguna SIA berpengaruh positif terhadap kinerja indivual. Hasil penelitian tersebut mendukung teori Technology Acceptance Model (T AM) yang menyatakan bahwa perilaku pengguna suatusistem informasi bergantung pada persepsinya mengenai kebermanfaatan dan kemudahan penggunaan sistem tersebut. Semakin baik kemampuan teknis yang dimiliki oleh pengguna suatu sistem, akan memberikan persepsi ba hwa sistem tersebut mudah digunakan.

Persepsi kemud ahan yang dimiliki oleh pengguna sistem serta manfaat yang dirasakan dari penggunaan sistem tersebut akan memunculkan niat untuk menggunakan sistem dengan lebih optimal, semakin optimal sistem tersebut dioperasionalkan akan memberi manfaat yang maksimal berupa peningkatan kinerja individual. Teori Technology-to-Performance Chain (TPC) juga menjelaskan agar suatu teknol ogi infor masi membe rikan dampa $\mathrm{k}$ posit if terhada $\mathrm{p}$ kin erja indiv idual, maka teknologi tersebut haru s diman faatkan secara optimal. Suatu sistem dapat dimanfaatkan dengan optimal, apabila pengguna sistem tersebut 
memiliki kemampuan teknis yang memadai. Semakin baik kemampuan teknis yang dimiliki oleh pengguna suatu sistem, maka akan muncul persepsi bahwa sistem tersebut mudah untuk dioperasionalkan. Persepsi kemudahan ini akan memberi dorongan kepada pengguna sistem untuk mengoperasionalkan sistem dengan lebih efektif. Semakin efektif suatu sistem dioperasionalkanakanmemberi dampak pada peningkatan kinerja individual.

\section{SIMPULAN}

Berdasarkan hasil penelitian yang telah diperoleh melalui pengujian statistikdan pembahasan yang telah diuraikan pada bab sebelumnya, maka dapatdisimpulkan bahwa, semakin efektif penerapan suatu sistem informasi akuntansi dan semakin baik kemampuan teknis yang dimiliki oleh pengguna suatu sistem informasi akuntansi, maka kinerja individual akan semakin meningkat. Sistem informasi akuntansi yang efektif menandakan sistem tersebut telah dioperasionalkan dengan optimal. Apabila suatu sistem telah dioperasionalkan dengan optimal, maka akan memberi manfaat yang maksimal berupa peningkatan kinerja individual. Kemampuan teknis yang memadai yang dimiliki oleh penggunasuatu sistem membuat pengguna sistem akan merasa semakin mudah dan nyaman dalam mengoperasionalkan sistem informasi akuntansi saat mereka menyelesaikan pekerjaannya sehingga kinerja individual akan meningkat.

\section{REFERENSI}

Alannita, N. P., \& Suaryana, I. G. N. A. (2014). Pengaruh Kecanggihan Teknologi Informasi, Partisipasi Manajemen, Dan Kemampuan Teknik Pemakai Sistem Informasi Akuntansi Pada Kinerja Individu. E-Jurnal Universitas Udayana, 1, 33-45.

Bodnar, George H, and W. S. H. (2006). Sestem Informasi Akuntansi (Buku 1). Jakarta: Salemba Empat.

Davis. (1996). Technologi Acceptance Model.

DeLone, W. H., \& McLean, E. R. (1992). Information Systems Success The Quest for the dependent variabel. Infomation System Research, 3(1), 60-95.

Dewi, N. L. A. A., \& Dharmadiaksa, I. B. (2017). Pengaruh Efektivitas Sia, Pemanfaatan Ti Dan Kemampuan Teknis Pemakai Sia Terhadap Kinerja Individu. E-Jurnal Akuntansi Universitas Udayana, 18, 386-414.

Dewi, N. M. U. S., \& Suardikha, I. M. S. (2015). Pengaruh Kemampuan Teknik Pemakai Sia, Partisipasi Manajemen, Insentif, Faktor Demografi PadaKinerja Individu. E-Jurnal Akuntansi Universitas Udayana, 13(2), 446-460.

Garrison, G., Wakefield, R. L., \& Kim, S. (2015). The effects of IT capabilities and delivery model on cloud computing success and firm performance for cloud supported processes and operations. International Journal of Information Management, 35(4), 377-393. https://doi.org/10.1016/j.ijinfomgt.2015.03.001

Ghozali, I. (2016). Aplikasi Analisis Multivariate dengan Program IBM SPSS 21 :Update PLS Regresi. In Semarang: Badan Penerbit Universitas Diponegoro. Semarang. https://doi.org/10.2307/1579941

Gita Sari, N. L. P. D. (2018). Pengaruh Efektivitas Penggunaan Kepercayaan dan Kualitas Sistem Informasi Akuntansi Pada Kinerja Karyawan PT. Indonesia Power Unit Pembangkitan Bali. Skripsi Fakultas Ekonomi Dan Bisnis Universitas 
Udayana.

Gunawan, Im. P. A., \& Tenaya, A. I. (2017). Pengaruh Efektivitas SistemInformasi Akuntansi Pada Kinerja Individual Dengan Kemampuan Teknik Personal Sebagai Pemoderasi. E-Jurnal Universitas Udayana, 20, 1621-1647.

Jayantara, I. ketut, \& Dharmadiaksa, I. B. (2016). Pengaruh Kemampuan Teknik Pemakai Dan Efektivitas Sistem Informasi Akuntansi (Sia)Terhadap Kinerja Individual. E-Jurnal Universitas Udayana, 17, 2145-2170.

Radhakrishnan Dewi, L. P., \& Dharmadiaksa, I. B. (2019). Pengaruh Efektivitas SIA, Kecanggihan Teknologi Informasi, dan Kemampuan Teknik Pemakai SIA pada Kinerja Individu. E-Jurnal Akuntansi Universitas Udayana, 27, 17351762.

Robbins, S. P. dan T. A. J. (2008). Perilaku Organisasi Edisi ke-12. Jakarta: Salemba Empat.

Sridarmaningrum, L. G., \& Widhiyani, N. L. S. (2018). Pengaruh Efektivitas Sistem Informasi Akuntansi, Kesesuaian Tugas, Kenyamanan Fisik dan Lingkungan Kerja pada Kinerja Karyawan. E-Jurnal Akuntansi Universitas Udayana, 23, 1955-1979.

Sugiantara, P. P. O. (2017). Pengaruh Penerapan Sistem Informasi Akuntansi, Kesesuaian Tugas dan Kecanggihan Teknologi Informasi Pada Kinerja Karyawan Dispenda Kota Denpasar. Skripsi Fakultas Ekonomi Dan Bisnis Universitas Udayana.

Trabulsi, R. U. (2018). The Impact of Accounting Information Systems on Organizational Performance: The Context of Saudiâs SMEs. International Review of Management and Marketing, 8(2), 69-73.

Widyasari, H., \& Suardikha, I. M. S. (2015). Pengaruh Kemampuan Teknik Pemakai, Efektivitas Sia, Dukungan Manajemen Puncak, Lingkungan Kerja Fisik Pada Kinerja Individual. E-Jurnal Akuntansi Universitas Udayana, 678697.

Yuhelson, Ariyanto, D., Ernawati, Soejono, F., \& Dewi, S. P. (2020). Digital economy and financial inclusion. Journal of Environmental Treatment Techniques, 8(1), 241-243. 